\title{
Mesolithic Research in Sweden 1986-1990
}

\author{
Kjel Knutsson
}

\begin{abstract}
The Mesolithic research in Sweden in the time period 1986-1990 is characterized as a whole by a processual epistemology and with an emphasis on interpreting finds rather than building theory. It is argued here that a shift toward more conscious theorybuilding geared towards understanding hunter-gatherers at the expense of excavation and interpretation, will be beneficial to Mesolithic research in Sweden.
\end{abstract}

Kjel Knutsson, Department of Archaeology, Uppsala University. Gustavianum, S-753 10 Uppsala, Sweden.

The commentary presented below on Mesolithic research in Sweden during the time period 1986-1990 will for natural reasons be both fragmentary and personal.

Anyway, my first impression after having read the 60-70 articles and books produced during the period was that the discussions were steered by "what I have found" rather than "what I have found out." The texts are further permeated by a neo-evolutionary epistemology often used in a rather occasional and, in my opinion simplified way. Especially achievements within middle range theory, which, if you want to work within a positivistic frame, is the implement per se, are almost invisible. To find a line between theory and data is not always easy. It would be overtly presumptuous and malevolent to say this without at the same time acknowledging the fact that the major part of the texts consists of accounts of rescue excavations which have taken place throughout the country. Quite clearly the lack of thorough theory, even within the neoevolutionist stance, for the most part has to do with lack of time to deal with methodological and theoretical issues on the part of the writer. Theorybuilding is always conducted from outside, so to speak. Therefore, the first critical lines of this article must be seen as an implicit critique of the way we as archaeologists interpret the cultural heritage legislation. Civil servant "errand handling" tends to conserve temporary scientific ideas as interpretative standards and use them too long. Because archaeologists as a group are responsible for this view of the meaning of the legislation, no one can escape the responsibility to try to change it. Myself included.

One of the things I feel a lack of in the Swedish papers on the Mesolithic is a serious debate on what hunter-gatherers actually are and what there possibly is of interest to know about such people, apart from the fact that they hunt and gather. The anthropological controversy between the neo-evolutionists and "revisionists" is one way of opening us up to what fundamentally characterizes $\mathrm{HG}$ as humans and inspiring us to think differently and perhaps even excavate differently, especially when it comes to the Mesolithic-Neolithic transition. (Lee 1992; Testart 1988; Tilley 1989).

Basically then I think, for reasons stated, that during the period 1986-1990 we have seen too much "Mesolithic" and too little "hunter-gatherers" in Swedish Mesolithic 
research. But, as Emils father in the story by Astrid Lindgren tells Emil when being asked if it is not time for him to visit the woodshed after a day loaded with mischief: "That should not be neccessary, one has to admit that you have accomplished something good too."

\section{THE SOUTH COAST AND LARSSON'S SKATEHOLM}

The discussions and publications from the time period have been dominated by a few major excavations resulting in fundamentally new information on late Mesolithic, probably hunter-gatherer cultures of southern Sweden. Outstanding is the Skateholm project. Launched already in 1980 , it has been partly published in a major book during the period (Larsson 1988) as well as in smaller articles in journals in Sweden and abroad. Lars Larsson alone actually accounts for $30 \%$ of the published papers on the Mesolithic in Sweden during the period. Indeed a remarkable effort.

The major book is structured much the same as most serious studies of Stone Age sites: a short archaeological contribution backed by a series of specialist reports "interdisciplinary studies" - on fauna, palaeoenvironment, dentition, use-wear, etc. But contrary to a normal book, this one, according to the author, is expected to be followed by a more anthropologically oriented one. This first book may thus be seen as a kind of database for subsequent social analysis of a late Atlantic society. We are looking forward to that.

The book contains detailed analyses and descriptions of geology, palaeoenvironment, fossil fauna, physical anthropology and flint tool use-wear. The specialist reports are written for specialists with a specialist language and data handling. To me as an archaeologist, the palaeoenvironmental reports, including pollen analysis, macrofossil analysis, diatom analysis and insect fauna analysis, could only be evaluated through summaries, which gave me the general picture of a lagoon forming where the sites once were situated, with increasing depth, size and salinity throughout the Atlantic period due to a general transgression that eventually ends in the early Subboreal. I appreciated the taphonomic direction of the fossil fauna report with its informative discussions of cultural effects on assemblage composition. I was also impressed by the multitude of information one can extract from people's teeth, including such things as the division of labour between sexes and the identification of family groups. The interpretation of flake axes as multi-purpose tools did not surprise me (for an earlier analysis of flake axes see Knutsson 1982), although I might question the selection of these exact tools for analysis. An analysis and a classification of tools must be geared of course, as any scientific enterprise, toward answering certain questions. I could not find these questions, however.

As a whole the book is loaded with information, and it has the will of course to be of vital importance to Mesolithic research in general. The problem, however, as I see it is that the structure of the articles seems to be dictated by some inductive hope that large amounts of data will result in knowledge. They do of cource, but not only that. By the very nature of their ability, reliability and detail, they will forcefully shape the cultural interpretation as to both content and character. This is not altogether a good thing. In a sence, then, this might be seen as a mild form of the tyranny of method. But I must admit, turning to my explicit, though masochistic positivism, it is a nice tyranny.

\section{FUNCTIONALISM-SYMBOLISM}

Larsson is one of few writers in the period to adopt a post-processual language. In articles like Big Dogs and Poor Man and Dogs in Fraction - Symbols in Action 
(Larsson 1989; 1990e) he explicitly deals with the symbolic interpretation of funeral remains and even introduces some sort of textual approach to archaeological interpretation, using a grammatical metaphor. The articles must be seen, however, as an adoption of themes taken up within the postprocessual school, and not as a fundamental change in the basic view of a positivistic epistemology. This is also true of a second author moving towards a symbolic archaeology: Taffinder in her paper on the selection of lithic materials as evidenced by variations in flaked industry on Mesolithic sites in eastern middle Sweden (Taffinder 1987). In this interesting article Taffinder asks a simple question that is hard to answer: Why is it that stone-tool raw materials vary among sites? Can it be explained by raw material availability, by responses to utilitarian needs, by flakability, or some other non-functional cause? Although these questions have been asked before, she is one of few researchers in the period to try to follow them up by presenting a survey of anthropological discussions of these issues, which indicate both utilitarian and symbolic reasons for the selection of tool raw material. She explicitly searches for interpretative theory. She also touches upon the Gould-Binford controversy over embedded versus expedient extraction of tool raw materials. She also mentions symbolic values related to stones, like stones from "sacred sites", the taboo for women to use cryptocrystalline rocks, or when they are related to the maintenance of social networks. Basically, then, she comes to the conclusion that "non-utilitarian aspects influence raw material selection"; that is, functional explanations are neither very efficient nor interesting when used one-sidedly to explain variability. In an archaeological case-study based on a few sites in eastern middle Sweden containing flint, quartz and porphyry, she sees that: formal tools are almost exclusively pro- duced out of exotic flint; the bipolar method is very common in quartz assemblages; the platform method dominates the flint assemblages; sites of different age have different composition of exotic versus local raw materials. Finally, she makes a study of the raw material availability in the surroundings and concludes that all raw materials found on the sites are local except for flint. The interpretation of this pattern is denied the reader, however, though it really does not matter: the point has been made. A new world of ideas is needed to be able to explore a topic like utilitarian versus symbolic values.

Lars Larsson presents a similar but more inductive discussion of raw material variability on late Ertebølle sites, as a measure of either seasonal movements of HG groups or exchange between groups (Larsson 1987; 1988a). Not only flints but exotic items like aurox teeth and elk teeth are discussed and taken as examples of "trade," in connection with women's clothes decorated with teeth. The presence of Linear Pottery axes in the late Ertebølle sites further indicates contact between the farming and hunter-gatherer communities. These axes are not seen as symbolic items without a reference, but as a symbol of knowledge. A knowledge related to the specific use to which these axes where put, i.e. making planks (See also Larsson 1987).

In another paper on funeral ritual, Big Dogs and Poor Man (Larsson 1989), Larsson discusses the ritual code of Mesolithic groups. Basically, then, he tries to evaluate the variability in burial rites illustrated by the placement of the graves in relation to the settlement site, as well as the different ways of placing the body, arranging the grave-goods, etc. He comes to the conclusion that the position of the graves has to do with societies marking land rights and that they are ritualized. Not only the graves are elaborate but also the rituals preceding and succeeding them. He sees for example, 
indications of funeral meals and things thrown into the graves when closing them, as well as constructions put over the graves. Larsson compare this complex set of rituals with the ways dogs have been treated after death. They are not treated equally. Some dog graves are so "rich" that the dog must be called a "big dog", at least according to a simplistic theory stating that rich graves mirror importance in life - a theory criticised by Larsson of course. Dogs have also been covered with red ochre, and most of them seem to have been buried in a special area of the burial-ground. In a sense, then, Larsson uses the dog burials as a sort of critical appraisal of archaeological ideas on the relation between material culture and status, especially in studies of hierarchical societies through their graves. However, in a discussion of the Skateholm burial-ground in another paper he states: "One could perhaps expect that the ceremonies and conceptions, that was tied to burials, should be less complex during an earlier part of prehistory than during a later. The finds from Skateholm has shown that this is wrong" (Larsson 1986a). Thus, here he is implicitly accepting the complexity of burial ritual as a measure of societal complexity. On this point one would have liked a reference to the revisionist critique in anthropology.

Regarding dogs, Larsson continues to discuss them in Dogs in Fraction - Symbols in Action. He takes up a theme centering on the problems of understanding symbols in prehistory and pursues a dialogue where "questions are provoked by the graves" (Larsson 1990e). A linguistic metaphor is used to illustrate the "code" of the graves. Larsson uses expressions like language, dialect, syntax, grammar, etc, when taking up themes like the position of the burial ground as a possible symbolic expression (See also Larsson 1988a), the orientation of graves according to different sexes, physically related individuals exclusive right to certain parts of the burial ground, ceremo- nies surrounding the burials, the burial of dogs etc. In this inductive reasoning Larsson really opens up a kind of hermeneutic dimension in his text, provoking ideas to follow up on. The lines of thought are not given so much substance in his paper as one might have wished in a true hermeneutic back-and-forth movement, but that was perhaps not the point of writing it in the first place. That would have meant a complicated and time-consuming broadening of views through anthropological reading and experience. The point of the article was to open up and provoke questions, not investigate them.

Larsson's contribution to Mesolithic research must of course be appreciated, but since I set out to be critical I would have liked to see a smaller number of papers in favour of more explicit and personal involvement in hunter-gatherer theory-building. As it is now, I feel that Skateholm through it's novelty and complexity kept Larsson physically too much in its power.

\section{THE WEST COAST AND BLANKED SITES}

Several decades of rescue excavation of Mesolithic sites in the Gothenburg area have been presented during the period in a thematic book on the "blanked sites," which to a Swedish archaeologist means the same as a discussion of the "Sandarna culture" (Andersson et al 1988). It is the first comprehensive summation of this cultural phase, and though it is written for a general public it has basic information of interest to the practising archaeologist as well. It is written within an overtly processual tradition, and like the Skateholm book, is characterized by the collaboration with "specialists" within fields like palaeoethnobotany, faunal analysis and radiometric dating. This gives the book a trustworthy base; although in these contributions I missed a critical taphonomic discussion of representativity as well as a developed 
idea on the relation between the character of finds and human action. The anthropology of the Sandarna culture, though nicely illustrated, is rather meagerly treated. It is characterized by "pick-and-choose ethnography," with only weakly argued for connections with the archaeology of the sites discussed. The connections, I am sorry to say, are not relational but formal. I also missed a more informative treatment of the main source material for the social interpretation of Stone Age sites, i.e. the stone tools, especially since this source material dominates the text. Regarding tool production and tool function, the results of 15 years of low level, middle-range research within the processual tradition, are totally left out. This is all the more strange as the results are widely accepted and known. They have not been published in obscure journals somewhere in the outposts, but actually to a great extent in Swedish and Danish journals (see e.g. Knutsson, H. 1982, Knutsson, K. 1988, Juel-Jensen 1985). I cannot understand the rationality behind this omission.

One of the good points of the book, however, is the archaeological characterization of the Sandarna culture. Only wellstratified sites have been selected as a database. Thus the lithic industry is chronologically well defined. Personally I was pleased to see that the handle-core tradition is not found in any of the well-stratified Sandarna culture sites. This makes sense in a wider Swedish chronological and developmental perspective. The evaluation of the Norrlandic Mesolithic, if seen from a south Scandinavian chauvinistic perspective, is kicked in a new direction.

A newly excavated site of the Sandarna culture, south of Gothenburg, must be mentioned in this context. The site is presented in popular accounts by Bengt Nordqvist, who led the excavations (Nordqvist 1989). The Balltorp locality is dated by $\mathrm{C} 14$ datings and shoreline displacement to the early part of the Sandarna culture. The clay-covered cultural layer contained a fossil fauna assemblage - the first such found in a settlement in the inner part of the archipelago in the area. Noteworthy is also the presence of skew-edged arrowpoints of the early 'Hensbacka type," to my knowledge the first such to be found on a blanketed site. Balltorp is thus of importance to the interpretation of the Sandarna culture's economy and chronology, but it also has implications for the understanding of the relation between the Hensbacka phase and the Sandarna phase.

The meager representation of faunal assemblages on Mesolithic sites on the west coast has been further enriched during the period with a fossil fauna material from one of Sweden's few shell middens. The brief report in Populär arkeologi by Eva ShallerÅhrberg and Hans Kindgren (1990) on the midden at Röe, close to Lysekil, informs us of a site with great potential. Stone tool assemblages put the site in a Lihult tradition. Large quantities of animal bones were found when probing the site, not only refuse fauna but bone tools. Another interesting aspect of this site is the discovery of a human skeleton in the midden during roadwork in the late nineteenth century. Possibilities of recovering burials on this site should therefore be good. Maybe a new Skateholm? It would be the first Mesolithic burial-ground outside the Ertebølle tradition in Scandinavia, and would contribute significantly to the current debate on the territorialization of band societies, dialectic tribes, etc in late Mesolithic North-western Europe.

\section{MESOLITHIC TERRITORIALITY ON THE ISLAND OF GOTLAND IN THE BALTIC}

A third major publication on the Mesolithic is Inger Österholm's doctoral dissertation on the Stone Age of Gotland (Österholm 1989). Her aim is to study settlement pattern and social structure during the Mesolithic and Neolithic. Before commenting on the text, 
it must be acknowledged that Österholm has put a lot of effort into locating and surveying new sites and has thus made a major contribution in forming a database for discussing territories and economy during the Stone Age on Gotland. What is missing, however (perhaps therefore?) is theoretical cogency.

Österholm's dissertation falls into the general positivist pattern of writing during this period, with an overemphasis on hard science means to extract data (phosphate, pollen- and technical analysis of ceramics, etc) at the expense of anthropological theory. A discussion of social theory, in this case a theory which should have been geared towards understanding basic principles of territoriality and economic behaviour among hunter-gatherers, is almost totally lacking. One of the interesting parts of this disseration is, namely, the observation that the settlement pattern follows the ancient coastline in a regular pattern. A pattern which does not seem to be related to environmental constraints and possibilities and should thus be socially constituted. Base camps and extraction camps are seen as clusters at $20 \mathrm{~km}$ intervals. Finds in the territories indicate that the territoriality continues from the Mesolithic to the Neolithic. Parallel developments in mainland Sweden and on Gotland further indicate a larger area of cultural contact.

A similar idea about late Mesolithic territoriality and, thus, incipient social complexity in Scania is actually offered by M. Larsson (1986). He views the presence of large "permanent" settlement sites and burial grounds (Skateholm) as indicators of a "need to control land", and small settlement remains as indicators of specialized task sites within the coastal territory. The territory is formed around nutrient-rich lagoons along the ancient coastline (see also Karsten 1986 and Larsson, L. 1987 for similar views).

\section{MESOLITHIC-NEOLITHIC \\ TRANSITION}

The economic interpretation of the Gotlandic Mesolithic by Österholm is by necessity nature-deterministic. The source material used for the economic interpretation is too meager to allow anything else. Österholm is further conformistic as regards the interpretation of the transition to a Neolithic economy on the island. She sees the transition as; a) caused by major ecological changes and $b$ ) as begun already in the late Mesolithic due to stationary $\mathrm{HG}$ coastal settlement favoured by a rich natural environment in this period. Charcoal particles in pollen samples dated to the late Mesolithic as well as finds of axes in the inland areas further indicate manipulation of the landscape by hunter-gatherers, either to improve the conditions for big game or as a result of a slash and burn economy. In this view of the stationary and complex late Mesolithic HG groups she echoes the revisionist ideas shared by Lars Larsson (1986a) and Mats Larsson (1987) (see Brown and Price 1985 for further examples of this view).

An ecological change that has to do with the water-level changes in the Atlantic, causing less flow of fresh saltwater into the Litorina sea and resulting in less favourable conditions for animal and plant life, is hypothesized. The favourable coastal economic base is thus lost, forcing people to adopt a more inland-oriented strategy. A similar interpretation of the final huntergatherer phase in southern Sweden is exemplified by the Skateholm and the Ystad projects. Here, the development of nutrient-rich lagoons (where the ancient settlements are found) is seen as an incitement to a stable and almost sedentary way of life in the late Ertebølle phase, bearing with it an incipient social complexity. In the late $\mathrm{AT}$, however, in connection with a deterioration of climate, sandbars develop in the lagoon mouths along with small 
transgressions. A regression initiates, the lagoons grow over, and the base for the stable late Mesolithic economy is lost. An inland component, the hunting of forest animals, is hypothesized (cf. Österholm on this point) as shown by the inland distribution of late Mesolithic Limhamn axes (Larsson, L. 1987; Larsson, M. 1987; Karsten, 1986) and CIP pollen in pollen cores from the interior (Larsson, M. 1987).

The explanations for a change to a Neolithic economy within the Scania-Gotland group are basically nature-deterministic in that the climatic deterioration forces the late mesolithic HG groups to "find new strategies for subsistence." This concensus is, however, challenged by Jennbert (1984), who sees the change as socially constituted, created as a response to a developing social network between northern HG groups and the Continental farming communities. Through marriage alliances and exchange, the Neolithic economy and material culture slowly became integrated into the HG culture. The relative sedentariness, with, as a consequence, delayed return systems of the late Ertebølle groups, is a prerequisite for this interpretation theoretically applying to the marxist movement in archaeology in the late seventies.

\section{BORDER PROCESSES}

This discussion of the interaction between HG groups and farming communities automatically moves us to border or frontier processes, that is, interaction between groups of peoples such as hunter-gatherers and farmers along a border zone. Hyenstrand (1987) sketches a research program for the study of border processes, taking as his point of departure the "Limes Norrlandicus" in middle Sweden. Here it is obvious that a borderline of great antiquity between groups of peoples can be found. According to Hyenstrand, it is not until the early Iron Age that sedentary groups infiltrate the northern hunting grounds. During the en- tire prehistoric period, including the Mesolithic, this area must have been the scene of social, ethnic, economic, etc., border processes, including conflict, trade, ethnic construction, etc. The explicit stating of a fundamental question with its conceptual frame is attractive, but the paper is too brief to be evaluated. My personal view is that Hyenstrand, like many other researchers who discuss interaction between foragers and settled groups, seems to take for granted that the benefits of a settled life "infiltrate" the hunter-gatherer populations, never the other way around.

Regarding frontiers and human interaction at borders, it may be worth mentioning that, apart from the "Limes Norrlandicus," an area with potential for looking into the dynamics of forager-settled groups should be the Smanland highlands. Here, Mesolithic HG groups may have remained during part of the neolithic (Högberg 1987), forming an interesting subject for ethnicity discussions, i.e. the formation of ethnicity along a border between two different economic and/or social systems.

Although based on a "Neolithic" source material, Tilley's discussion of the relationship between the Pitted Ware culture and the Battle-Axe culture (Tilley 1989) is more specifically oriented towards the fundamental question of border processes, and thus also applies to the discussion of the change to a Neolithic economy. He discusses the dynamic relationship between catchment groups and farmers based on explicit anthropological theory and the idea that material culture is seen as meaningfully constituted and actively used in the process of interaction. Theoretically this paper has thus direct interest for Mesolithic research, because it makes at least an attempt (one of few papers to do so) to study what huntergatherers actually are, instead of merely giving a stereotypical view of their economy. In his evaluation of the relationship between the Pitted Ware culture and the 
Battle-axe culture, he comes to the conclusion that: "Through time it can be suggested that social stresses and tensions may have developed as a result of the continued coexistence in spatially contiguous areas of two opposed economic, social and ideological systems: the relatively stable agrarian social groups represented by the BAC tradition and the more flexible and fluid sets of social relations represented by the PW tradition." He further acknowledges the observation by Hodder that: "We might expect an increasing stylistic separation of social groups relating to the use of material culture to support their identity in periods of increasing social stress"..."... with the stress and uncertainty being faced by the agricultural populations because of their inability to establish any permanent links with the fluid hunter-gatherer social networks" (Tilley 1989:280). All this is evidenced by an expanded ritualisation of BAC burial customs, a separation of graves from settlements, a structural distinction of BAC pottery versus PW pottery, etc., over time. Having discussed this, Tilley goes on to suggest that: "Contemporary hunter-gatherers...may in no sense be comparable to groups in the Pleistocene Europe or the United States. Provocatively, what we may be witnessing in the late middle neolithic of Scania is the development of such a form of huntergatherer social organization in contact with farming populations" (Tilley ibid). In other words, the fluid set of social relations so typical of HG is the result of an active effort to retain social and ethnic identity, to escape the "colonial" wish to control the settled groups. This is, of course the important message from Tilley with reference to anthropological observations of HG. In this, Tilley - the only writer to discuss Swedish HG groups during the period 1986-1990 takes an explicit position in the revisionist critique of the neo-evolutionist stance. This discussion still flows through the anthropology of the HG (e.g. Testart 1988 and Lee
1992); and it is here that I would like to see an explicit commitment from Swedish Mesolithic researchers because the discussion obviously has fundamental impact on the way we approach HG studies and what we think we are doing when discussing "the Mesolithic."

As such the PW culture offers another unique possibility of study (if we think we can use modern HG as a reference) which is not discussed by Tilley; namely, how once settled groups gradually developed towards an $\mathrm{HG}$ economy. Here the fundamental processes of change and the logic in sequential stages of change must be possible to discuss.

\section{LITHIC TECHNOLOGY AND SOCIETY IN MIDDLE SWEDEN}

The fourth major book on the Mesolithic, Callahan's (1987) treatment of the lithic technology of Stone Age sites in eastern middle Sweden, discusses the problem of migration or diffusion of ideas in the late Mesolithic-early Neolithic transition, but from a totally different standpoint. Based on a series of experimental simulation of tool production, he creates an understanding of and a techno-typological instrument with which to evaluate the lithic technology of the multi component site of Lilla Mark, situated on the Swedish east coast close to Oskarshamn. Looking at the stone tool production during the Mesolithic and Neolithic, Callahan comes to the conclusion that there are no major shifts in the technological tradition in the area during the transitional period. The change in economy is thus not related to any change in the way tools are made, which indicates that the spread of a Neolithic economy was primarly the result of a diffusion of ideas. Callahan's problem is basically of a source-critical character. The Lilla Mark's site internal chronology is based on shoreline displacement and the idea of shorebound settlement. Successive plateaus are seen as Mesolithic, Neolithic, etc. Obviously 
there may have been a mixing of materials during the course of settlement. In spite of the complicated source material and the cultural interpretation based on it, I think that Callahan has provided a major contribution to Mesolithic research in middle Sweden. He has, so to speak, "opened up" the quartz and porphyry lithic assemblages - so typical of most assemblages north of Scania - to social analysis. On account of their fracture patterns, these materials typically break up during knapping into apparently incomprehensible fragments. Thus, the study of the Mesolithic in these areas has been severely hampered. Callahan, through his analysis, has provided an incitement as well as an instrument for archaeologists to deal with these sites as the result of human action.

Other minor contributions to the technological understanding of flaked assemblages pertinent to the discussion of non-flint sites have been made during the period by Thorsberg (1986) and Knutsson (1986).

The value of this opening up of seemingly incomprehensible quartz-dominated settlement sites in middle Sweden to social analysis is further enhanced in the light of the successful survey and excavation work carried out by the Central Board of National Antiquities in the period 1986-1990. In Gästrikland, Värmland and Dalsland (Arkeologi $i$ Sverige 1986-1990) several hundred new Stone Age sites have been discovered, most of which are characterized by flaked quartz industries. All of these surveyed sites are the material remains of seasonal movements of hunter-gatherer populations living in the above-mentioned border zone, the Limes Norrlandicus, between settled populations and catchment groups.

On the Swedish east coast, in the same area as Oskarshamn, a Mesolithic site (also dominated by flaked quartz) has actually been excavated during the time period (Lindgren 1991). The site, Leverstad, is of importance because it is not a mixed site like the Oskarshamn site but a short-term settlement. Its potential lies in the possibility to begin characterizing the technology and structure of the east Swedish Mesolithic, which is basically a blank page in Swedish archaeology.

A remarkable contribution to the understanding of the Mesolithic in the southernmost part of eastern Sweden is further given by the survey work carried out by Kalmar läns Museum in the county of Kalmar in the mid-1980s (Westergren \& Hansson 1987). In collaboration with local folklore societies the museum antiquarians managed to discover 261 Stone Age sites, of which at least 40 are of Mesolithic character - this in an area of Sweden where scarcely any Stone Age settlement sites were earlier known.

\section{FUNCTIONAL ANALYSIS}

The possibility to give human meaning to all these newly discovered sites in middle and eastern Sweden has been further enhanced not only through the methodological progress within technological analysis as exemplified by Callahan's work, but also within functional analysis. Functional analysis until the mid-1980s had mainly been concerned with raw materials like flint, a material only sparingly present in the quartz- and porphyry-dominated sites in the surveyed area. In an article presented in the proceedings from the Lithic Usewear conference in Tübingen in 1985 , Knutsson \& Taffinder (1986) present some preliminary results from experiments within use-wear analysis of porphyry assemblages. Although complicated by the fact that porphyry is made up of a combination of different minerals with variable hardness and chemical structure, a functional analysis of these types of assemblages should be possible, according to the authors, at least within certain interpretative limits.

My own methodological work within lithic use-wear analysis concentrating on quartz as a tool raw material, gives further 
hopes for the future regarding the possibility of making comprehensible the newly discovered Mesolithic site materials in middle Sweden and also, of course, the assemblages from the north Swedish sites, dominated as they are by flaked quartz (Knutsson 1986; 1988a).

But being informed about tool use and tool production does not necessarily make it easier to interpret the site materials. Only by putting the functional and technical information in a network of specifically designed social theory and middle range theory will an interesting and meaningful dialogue between past and present develop. The application of use-wear as an analytical tool in social studies has thus been presented during the period in a conference book with papers from the seventh lithic use-wear conference held in Uppsala in 1989 (see Gräslund et al 1990). Reading the book it is obvious that this type of theory for the most part is still lacking (see Thorsberg 1984, 1990 and Ramos-Millán 1990); but the mere fact that these types of materials can now be given functional and technological "meaning" will be an incitement to pose questions of more general interest similar to Tilley's on $\mathrm{HG} /$ farming community interaction - and thus create a milieu where questions can be asked and appropriate theory developed.

\section{THE TINGBY SITE AND LATE BOREAL SETTLEMENT STRUCTURE}

A unique mesolithic site is represented by the Tingby site, found in 1987 just outside Kalmar in south-eastern Sweden (Westergren \& Rajala 1989). At the site remains of a small house were found, which are spatially correlated to a lithic industry dated typologically to the late Boreal Maglemose culture. The assemblage contains debitage as well as formal tools like scrapers, lanceolate and triangular microliths, core axes and flake axes. The unique character of the find was further enhanced by the fact that a large part of the typologically south Scandinavian assemblage was made of local porphyry, and by the fact that the site was shorebound during the settlement period - a rare feature of the Maglemose culture in southern Sweden, where most coastal sites are now submerged. The sites topography is closely reminiscent of the lagoon sites of the late Atlantic Scanian coastal sites, and thus offers a late Boreal comparison (for other mesolithic lagoon sites in the area see Westergren \& Hansson 1987). This should, of course, be of value, since much of the social and economic interpretation of the latter is based, as we have seen above, on the idea of rich coastal resources forming a base for stable settlement and thus gradual social change towards stratification in late Atlantic time. The east Scanian inland Ertebølle and Maglemose sites, excavated and published by Strömberg (1986) during the period, have to be mentioned in this context. They are situated at some distance from the sea and must be apprehended as small task sites (hunting stands?) because they are characterized by small scatters of debitage and splinters together with projectile points. No big sites seem to be found in the inland area. Contemporaneous coastal sites are under water and can not be investigated. Sites of this character have actually been discovered off the coast of Scania (Larsson 1988a). In a discussion of the possible coastal/inland dynamics of the Boreal Maglemose culture, Larsson mentions both inland sites and "coastal sites" found at the bottom of the sea. Anyway, the Tingby site can thus be seen as a seasonal coastal site similar to the submerged sites found by Larsson off the Scanian coast, and complementary to the small task sites like those discovered by Strömberg off the coast in south-eastern Scania. Similar inland task sites should therefore be expected in the Kalmar inland area. A lot of inland sites have actually been found during survey work by Kalmar Museum but so far they have not been 
thoroughly evaluated and discussed.

The age of the house correlated to the flaed assemblage has been questioned by other Swedish scholars (Johansson 1989). The question of whether it is a mesolithic house is still open, awaiting the final publication of the find. However, the presence of a rectangular house with a central row of posts in the late Maglemose culture is quite frankly, neither controversial nor surprising.

\section{NORTH SWEDISH HUNTER- GATHERERS}

In northern Sweden the Mesolithic economy expands at least into the south Swedish Bronze Age. Thus a broader chronological spectrum of archaeological writing should be incorporated into this treatment of the Mesolithic. Of the traditional Mesolithic contributions, one can mention the series of old C-14 datings from middle Norrland collected by Sundlin (1986). These dates are important because they present new sites to challenge the interpretation of the hitherto oldest site in Norrland, Garaselet. The Garaselet site, discovered in 1969, is dated to late Boreal time and its lithic industry is characterized by typical south Scandinavian, late Boreal/early Atlantic handle core tradition. Although several sites with handle cores have been located in Norrland since this discovery, nothing so old by comparison has been excavated. Thus the oldest phase of the Norrlandic settlement has been recognised for twenty years, and on very fragmentary evidence, as the "handle core phase," stretching from c. 6000 to $4000 \mathrm{BC}$. With the help of the newly discovered, very old sites presented by Sundlin, this idea of the early cultural development in Norrland can be evaluated. New find context's with old dates may be studied in detail.

The collection of papers presented in the same book as Sundlin's paper, Acta Borelia, published in Umeå, concerns settlements of hunter-gatherer origin in Norrland of a later date but should at least be mentioned in this connection. I need perhaps not elaborate on these presentations, which are concerned mainly with inland, fire-cracked mound sites, because they have been published elsewhere and thus reported in the former fiveyear evaluation period by Noel Broadbent (Broadbent 1987). The view of the firecracked mounds as houses is interesting, however, as is the idea that they represent local group centers in an annual exploitation system based in the interior of Norrland in the period $4000-2000 \mathrm{BC}$. This view may be correlated to the coastal sites from the same period, which were excavated and analysed by Broadbent (1979) and which are seen as semi-permanent in character and based on an annual hunting/gathering cycle solely using local resources. The diachronic cultural continuity of the coastal sites $4000-2000$ BC has been illustrated by similarities in lithic technology and hunting strategies by myself (Knutsson 1988b). Anyway, the two contemporaneous groups of settlements, one in the interior and one on the coast, are thus at present seen as two separate "groups" inhabiting and exploiting two different environments. In my opinion, this dichotomy between coast and interior should not be "explained" using nature-deterministic models as it is now, but rather be seen as a starting point for a discussion and treatment of the archaeological concept of "culture." A theoretical evaluation should be made of how material continuities and discontinuities can be seen as manifest expressions of group movements, taboos between different areas of exploitation, subgroup identity markings, etc. We do not know very much about these things, yet in interpretations we continually use implicit assumptions about questions of this kind. This north Swedish dichotomy will, I think, because of the richness of sites and finds, be of great value in such a venture.

Lena Holm's work on hunter-gatherer sites in the western high mountains has been presented in two short papers during the 
period, including one popular account. An evaluation of lithic industries in the TärnaRana mountains focuses on diachronic changes in technique and method, based on an analysis of brecciated quartz at the stratified Gräsvattnet site (Holm 1989; 1990). The deeper layers are characterized by hard hammer technique flakes and handle cores of late Mesolithic type, and the upper by soft hammer flakes attributable to the manufacture of flat-hewn quartzite points of Bronze Age character.

The fact that late Mesolithic handlecore sites are present in the high mountains may indicate a more logistic resource strategy for that period than has been suggested by Forsberg $(1986 ; 1989)$; this of course also implies a different social and economic development in that area. The late Mesolithic in Norrland is obviously still suffering from a representativity problem. More sites from the coast to the high mountains are needed.

Lars Forsberg's dissertation from 1986, although mainly concerned with "Bronze Age" settlement systems in Norrland, is the most explicit and theoretically conscious application of a processual, cultural-ecological approach to HG settlement patterns in the period. Forsberg sets out to discuss the prehistoric settlement pattern along the Lule and Ume rivers in the north of Sweden. In his access he had a database of sites excavated by the Central Board of National Antiquities along these rivers in connection with water power-station construction in the $1950 \mathrm{~s}, 1960 \mathrm{~s}$ and 1970s. The artefact material is classified into "functional" categories and types of raw materials. A series of multivariate statistical analyses separates the sites into types characterized by different artefact types, petrographic materials and site locations with respect to natural resources. Thus, with the aid of anthropological theory, Forsberg is able to classify the sites along the rivers flowing from mountain to coast into hunter-gatherer site types such as; base camp, activity camp, transit camp and agglomeration site. Fossil fauna material is discussed in order to further strengthen the arguments. An intrasite spatial analysis strengthens the arguments for the classification of the archaeological sites into different functional categories. Obvious differences in site layout emerge, including sites with hut impressions formed by bimodal flake scatters.

An annual settlement system is thus reconstructed for the Ume and Lule rivers. These ancient HG systems are highly logistic, commuting between the mountain areas and the coast. The coastal sites are as yet almost completely lacking but, Forsberg's model includes the necessary agglomeration sites on the coast, exemplified by the Stornorrfors rock-carving site.

One interesting thing about this dissertation, apart from its general importance as an explicit treatment of hunter-gatherer economy, is that a huge database comprising many sites in the interior of Norrland has been shown to be highly structured. The view of these sites prior to Forsberg's analysis was that they consisted of a palimpsest of chronologically separated assemblages in total disorder. As has been shown, this is not the case.

Compared with the Mesolithic and Neolithic periods preceding this "Bronze Age" hunter-gatherer coast-interior commuting, there seems to be no problem in viewing the sites along the river valleys as part of the same social group using different ecological niches.

\section{THE COMING GENERATION}

If seminar papers (C- and C-D levels) can be viewed as an illustration of the coming research generation then we are in deep trouble. During the period only 13 papers on the C-level dealing with the Mesolithic period have emerged from Sweden's five archaeological university departments.

Unfortunately I think that most of the 
papers are not geared towards theoretical or methodological issues in hunter-gatherer studies, i. e. understanding hunter-gatherers, but towards regional evaluations of archaeological finds resulting in presentations of a general "cultural development." This implies, ad hoc interpretations of find distributions from different time periods using a formalized neo-evolutionist concept in areas like Bjärehalvön, Höks härad, Limhamn, Värmland, Småland, etc (Andersson 1987; Gustafsson 1987; Högberg 1987; Jansson 1987; Pålsson 1987). Surveys of collections of finds are of course important, when creating databases, but as an inspiration to further studies of the Mesolithic one would prefer university papers to contain more theory and less empiri.

Another paper from Lund deals with seriation and artefact frequencies as a measure of the relative "popularity" of certain tools, which is thus used as a chronological instrument (Lindow 1987). The Bordes-Binford functional/normative controversy of the late 1960 s not even mentioned, despite the fact that it seriously evaluated just this concept. I personally think that there has developed a kind of archaeological concensus that variation in proportional artefact frequencies measures site function rather than diachronic changes in artefact popularity.

A paper on red ochre (Selling 1987) looks at the pigment as a symbolic device in different life situations, based mainly on ethnographic observations. The ideas are implemented in a study of Mesolithic graves, which indicates that "rich" graves more often show the presence of red ochre symbolism. In another paper, which takes as its point of departure the finds from the late Mesolithic Skateholm burial-ground (Rosberg 1987), the author discusses the role of the dog in Mesolithic society. The two latter seminar papers are interesting insofar as they pose questions of a specific character and try through comparative analysis, to deal with problems and not only with archaeological finds. The same can be said of the seminar paper from Umea which discusses territoriality measured by axe design (Lindholm \& Runesson 1990). Four territories are discerned in the southern part of Norrland. It is also noted that the large axes are predominating the farther away one moves from the biggest concentration of axes thought to be the central production areas. They are ritualized. In this paper the authors echo the work on social territories by their instructor Lars Forsberg at the same department (Forsberg 1989).

Bengt Nordqvist's discussion of the production and distribution on Lihult axes on the Swedish west coast and in the southern inland areas has some bearing on this problem (Nordqvist 1990); that is, it offers a possibility to discuss the dynamics between production and consumption areas. According to Nordqvist in his study of Lihult greenstone axes, there seem to be production areas for local consumption on the Swedish west coast; whereas production centers can be discerned in the inland areas from where there is a secondary spread through some societal mechanism (exchange, trade, warfare, etc).

In another seminar paper from Umeå, Eliasson \& Joelsson (1989) return to the interior-coast dichotomy by evaluating the finds of slate tools c. $4000-2000 \mathrm{BC}$. Their classification into knives, daggers, arrowpoints and spearpoints makes it possible to polarize the above-discussed inland Stone Age sites from the sites along the coast. The study results in a differentiation between the coast and the interior in the proportion of different tool types. This may be interpreted either as seasonal moves of one population between coast and interior or as the material effects of functional differentiation between two different groups. The latter explanation is most likely, according to the authors, because the winter settlement indications are present on both inland and coastal sites 
(compare Lundberg 1986; Broadbent 1979) and because the ecological conditions permit year-round exploitation of the two areas.

The whole point of the C-level paper is to induce some sort of scientific consciousness in the mind of the student. Excessive descriptive work and ad hoc interpretation may by all means result in some interesting ideas or patterns, but the educational value of such an approach is less obvious. Some of the Lund papers have this less favourable stamp and I feel I must mention that. The Umea papers and a few of the Lund papers show more of a stringent development towards a goal-oriented research-like situation. Basically, then, the coming generation is a "mixed grill" and much an echo of their senior teachers, with a few sparks in the dark that hold hopes for the future.

\section{INTRASITE SPATIAL ANALYSIS}

Intrasite spatial patterns, one of the cornerstones of processual Stone Age archaeology, are discussed in a few papers. Why? one might ask. What is interesting about intrasite spatial patterns apart from the fact that they have been part of the neo-evolutionist field of research?

Olausson's (1986) paper is a critical evaluation of attempts within Scandivanian Stone Age research to discuss intrasite spatial organisation. She bases most of her discussion on Schiffer's (1976) idea of formation processes. Most of the intrasite analyses carried out earlier are less wellfounded in theory. One exception is Thorsberg's seminar paper from Uppsala (1984), where Shiffer's ideas are explicitly adopted in a late palaeolithic case-study. In two papers dealing with late Mesolithic sites in Scania, intrasite spatial analyses have been carried out (Karsten 1986; Larsson, M. 1986). The papers are characterized by ad hoc interpretations and a strong tendency to see artefact deposition as primary refuse in Schiffer's terms - a trend that recurs in Nordqvist's paper on the Anfasteröd site
(Nordqvist 1990). In that sense they do not contribute much and actually is a step backwards compared to the seminar paper presented two years earlier by Thorsberg. One would also have liked to see some comments on why the intrasite discussion was generated in the first place. Let's hope that "intrasite analyses" will not become part of a descriptive "norm" when excavation reports are compiled. It is too complicated and valuable to be treated routinely.

In a seminar paper from Umeå University, Berit Andersson (1989) sets out to study the intrasite spatial organisation of six hunter-gatherer sites excavated along the Ume river in Norrland. Her aim is to compare the functional variation among sites of different "function" according to a classification made by Forsberg (1986) in his doctoral thesis. Site function in this case is mainly measured by scraper wear variation among sites. The spatial analysis is based on the distribution of tools and flake scatters. Although theoretically informed about the problems of site formation processes, the author, in my opinion, too easily interprets most of the material as primary deposition, that is, as indications of activity carried out where the tools are deposited. I further think that the methodological principles for lithic use-wear analysis developed during the last 15 years should have been adopted, instead of an almost 20-year old concept.

In this connection I must admit that I too have been making myself known in this type of analysis during the period. It is not a Mesolithic paper per se but a paper dealing with the problems and possibilities of intrasite analysis, exemplified by lithic scatters left on a former dune beach on the north Swedish coast by a huntergatherer population some 4000 years ago. An explicit base in neo-evolutionist theory for interpretation is used to show: a) the need of explicit theory when "interpreting" spatial distributions, b) the inadequacy of 
present processual theory for meaningful discussion of intrasite spatial behaviour, and $c$ ) the inductive value of a "functional" scenario in flaked assemblages.

Refitting and intrasite spatial behaviour are represented by only one paper, Birgitte Skars work on Baremosse II in Scania (Skar 1987). The late Maglemose site consist of a small, circular hut, in the center of which is a hearth. The lithic scatter comprises c. 20 square meters. The typology is characterized by scrapers, microliths, burins, burin blows, microburins, blades and cores. Forty-eight percent of the material was refitted, indicating an on-site production of tools. This notion was further enhanced by the presence of microburins and burin blows, i. e. production waste. The refitting resulted in the definition of seven blocks all starting out as cortex-covered nodules. A detailed description of technique and method in the reduction sequences is followed by an evaluation of how the debitage sequentially "moves" in the hut. Skar thereby discusses blankproduction, secondary modification, retooling, use, curation, etc., i.e. well within a processual world view and with a wish for functional explanations. The different craft activities defined are thus related to different areas within the hut; burin and microlith manufacturing debris is generally found on one side of the hearth, whereas scrapers are found on the opposite side together with awls and borers and a knapping floor. The blanks move from flaking floors to secondary modification areas. Phantom flakes are indicative of retooling, in which tools made on the site is abandoned hafted and moved away when the site was left. Skar ends the study not so much with an interpretation but with a series of questions: What does the spatial pattern mean in terms of factors related to age, sex, craft specialization, etc? Beside the fact that craft spezialisation is not what you immediately think of when dealing with hunter-gatherers, the fact that Skar ends with questions just shows that she has acknowledged the lack of explanatory theory in spatial analysis. The refitted material is, however, "forever true", and future research can thus return to this structured database over and over again and reinterpret it.

\section{SITE STRIPPING}

I was very pleased to see that the excavation of the late Mesolithic Anfasteröd settlement site on the Swedish west coast by Bengt Nordqvist (1990) was carried out by using an explicit "stripping-strategy." The goal, according to Nordqvist, was to arrive at possibilities of discussing settlement patterns, social relations, settlement layout, etc; In short, a contextual approach where features are seen as more important than artefacts. It is important that this way of approaching the archaeology of settlement sites is not restricted to sites of settled farming communities. As we know, during the last thirty years or so the approach - which first appeared on the Scandinavian scene in Denmark - has totally changed our understanding of Bronze- and Iron age settlement structures. Lately large-scale stripping of excavated areas has also contributed to the discovery and understanding of Neolithic settlements in Sweden (Björhem \& Säfvestad 1993; Tesch 1993). The effect of this approach on Mesolithic settlement sites is perhaps best shown by the Skateholm project results, but most is yet to be seen. However, besides Skateholm the explicit strategy adopted by archaeologists in the Gothenburg area must be acknowledged. It is not a coincidence, for example, that hundreds of Mesolithic sites excavated in the Gothenburg area during the last 30 years have resulted in only scanty evidence of habitations, not to say patterned settlement layouts (Andersson et al 1988). On the other hand, I must admit that I feel a little uneasy over the fact that all the evidence of site action/behaviour connected to find distribution, distribution of phosphates, etc is being lost with this 
method of excavating. A combination of "looking for finds" and looking for features by stripping must be developed. This is truly contextual. Personally I have lately been involved in designing excavations proposing and using stratified sampling and stripping of Stone age sites. A hermeneutic strategy based on repeated sampling and analysis before stripping the site (Knutsson \& Lekberg 1994).

\section{THE PUBLIC}

What has the general public found out about the Mesolithic during the period? Well, all the important new sites have in fact been presented in Sweden's popular journal, $P_{O}$ pulär arkeologi. Sites like Skateholm, Tingby, Balltorp, Anfasteröd, Röe and Bredasten are discussed (Larsson 1986a; 1986b; 1988a; 1989, Westergren 1988; Nordqvist 1989; 1990, Kindgren \& Schaller-Åhrberg 1990, Larsson, H. 1989). Furthermore, the major books on the Mesolithic have either been summarized (Österholm 1988) or reviewed in the same journal (Welinder 1989). Thus the correlation between field research and the public seems to be good. Well done, Swedish archaeologists.

\section{WHO WRITES?}

A simple statistical evaluation of the writers in Swedish local and national periodicals shows a clear pattern of male dominance. Out of 67 published articles and books, $70 \%$ were written by men. Only $20 \%$ of the papers were written by females, and $10 \%$ by a man and a woman together. We must be aware of certain source-critical points here, however, especially the impact of "the Lars Larsson effect." But even if we assume that he had published only one paper, which of course is ridiculous, the proportions are still $38 \%$ women and $50 \%$ men.

I do not know whether this is symptomatic only for the HG Mesolithic with its "male hunters" syndrome, or solely correlated to the different fortunes of the sexes after university graduation. It is striking, namely, that the $\mathrm{C}$-papers on the Mesolithic - the last effort of concentrated research for most archaeologists in Sweden during the period 1986-1990 are dominated by women (63\% female authors as opposed to $37 \%$ male). Can this be explained as such that "the few" men after graduation write more than "the many" women? This is probably the case. This has of course something to say not only about present-day gender relations but about how prehistory, including the analysis of hunter-gatherer societies, is pursued. For many years we have asked ourselves where the women in prehistory have gone. This is not the right way to put it. We must ask, where have the writing women in hunter-gatherer research gone? If we find them we will also find the women's sphere in hunter- gatherer societies and, wonder of wonders, we will perhaps come to the conclusion that there were children in prehistory as well. Their invisibility in archaeological analyses is only, I regret to say, surpassed by their invisibility in present daysociety. I personally complained about this state of affairs some time ago (1976; 1985; 1986) but to my knowledge nothing has happened since.

The notion of the absent women and children in Mesolithic research, or rather in Stone Age research in general, has, however, been commented upon during the period by a Norwegian colleague (Engelstad 1986) in the formulation of a research programme which to my knowledge is still living (Engelstad 1991). It is sad that gender studies now after a decade are slowly losing their value as a means to attain scientific prestige. At worst, this will mean that in Swedish HG research this type of discussion might never come to start.

\section{CONCLUSIONS}

What have I learned by this reading? What is the tendency in Swedish Mesolithic research? There seems to be at least one 
forceful idea penetrating the discussion of the late Mesolithic groups. This view may be called the Lund concensus because it is shaped and pursued there. It has to do with the economic and social change of late Ertebølle HG groups, initiated by a climatic deterioration in late Atlantic time which caused the rich lagoon sites on the coast to be abandoned in favour of an economy geared more towards the inland areas. Identical views pertain to the late Gotlandic Mesolithic. The preconditions for a relatively settled life were lost and alternative strategies of living were sought. The Neolithic sneaked slowly in. This view follows a general trend in European Mesolithic research, which maintains that $\mathrm{HG}$ groups in the later part of the Mesolithic became more and more settled and thus gradually developed a hierarchical or "complex" society (see e.g. Brown \& Price 1985).

Lagoon sites similar to the late mesolithic types have, however, also been found from the late Boreal Maglemose period at Tingby, close to Kalmar. Submerged sites off the coast of Scania point towards similar sites being present there too. The unique, high productive settlement environment of the late Ertebølle, seen as the precondition for a settled life and thus for an incipient complexity in these societies, may thus not have been so exclusive to that period as one might think.

The new directions in the Swedish national survey of ancient monuments, where non-visible monuments are looked for in structured surveys that include trial pits, have revealed Mesolithic sites in large numbers in areas (especially in middle Sweden) that were earlier almost devoid of settlement indications. Together with new methodological and theoretical achievements within lithic analysis, a whole new area of Sweden has been opened to hunter-gatherer research. This is especially interesting since the new materials are situated in an area which for thousands of years has been a border-zone between northern catchment economies and southern agricultural economies. The dynamics of border-processes may bee favourably pursued here, especially concerning questions such as the formation and maintenance of identity and ethnicity between two populations with fundamentally different ways of perceiving life. In other areas of Sweden, for instance in the Kalmar area, collaboration with local interest groups has proven invaluable in locating sites. This is something one might want to see expanded to other areas.

As expected, most of the papers are presentations of rescue excavations and thus short and descriptive. This may account for the feeling that one is looking at a theoretically slightly stagnating discipline. This in turn has been thought to result from the way we interpret the cultural heritage legislation, with an overemphasis on the practicalities of excavation at the cost of producing reasonable conceptual conditions for such an enterprise. I want this to be changed.

There is still a gender problem in Mesolithic research. After a dominance in C-level exams at the universities, women seem to disappear from the scene of writing archaeology. This in turn is seen as an obstacle to changing our views on the kind of archaeologies that would be of interest to us. The archaeology of hunter-gatherer women and children is asked for.

From a north Swedish perspective, the Mesolithic discussion is dominated by scientists working in the southwestern $10 \%$ margin of the country, an area which, however, is thematically identical to most of Norrland's prehistory. This has to do with present-day archaeological demography, but that is not the only reason.

There is a complex and rich hunter-gatherer material in the north of Sweden. New Cl4 datings indicate a widespread early Mesolithic tradition starting in late Boreal time. The whole cultural sequence from then on, until c. $4000 \mathrm{BC}$ has just begun to be 
visible. Actually, much of the theorybuilding and themes of the southern Mesolithic apply to the cultural development in Norrland up until $500 \mathrm{BC}$. Thus, much of the discussion is parallel. What is still lacking in this respect is Swedish archaeologists working personally with find materials from Norway and Finland. The present-day national state borders thus tend to act as borders of prehistoric cultural development. The idea of a growing societal complexity heralding the introduction of a neolithic economy in the late Mesolithic in Scania and Gotland, could also be discussed in a Norrlandic setting in the late Bronze Age. It was also noted in the paper that the interior-coast dynamics of the Norrlandic late Stone Age should be viewed as an area where the archaeological concept of culture can be pursued rather than be explained in a cultural-historical tradition. Later, the same area is further the scene of border-processes between inland HG groups and settled farmers on the coast.

In general, we can conclude that the postprocessual tendency in mainstream archaeology has in the period just barely managed to

\section{REFERENCES}

Arkeologi i Sverige 1986-1990. Riksantikvarieämbetet. Stockholm.

Alexandersen, V. 1986. Ett verktyg att tugga och arbeta med. Populär Arkeologi 4/4:18-21.

Andersson, B. 1989. En aktivitetsanalys av sex bronsåldersboplatser vid Umeälven. Seminar paper. Umeå.

Andersson, S., Wigforss, J. \& Nancke-Krogh, S. 1988. Fångstfolk för 8000 år sedan. Göteborgs Arkeologiska Museum. Göteborg.

Andersson, S. 1987. Värmlands äldsta stenålder. Seminar paper. Lund.

Björhem, N. \& Säfvestad, U. 1993. Fosie IV. Bebyggelsen under brons- och järnålder: Malmöfynd 6. Malmö Museer. Malmö.

Broadbent, N.D. 1979. Coastal Resources and Settlement Stability. AUN 3. Uppsala.

- 1987. Northern Hunting and Fishing Cultures- penetrate the surface of Swedish Mesolithic research. In a sense this is neither surprising nor necessarily very bad. What is worse, howewer, is that not even the achievements actually made within the neo-evolutionist, processual archaeology have (with few exceptions) been a forceful and informative part of the writing during the period. Thus to call for - which would be natural in my present position as a commentator - a more nuanced view of culture and epistemology that incorporates ideas generated within the post-processual movement, seems less meaningful. I will end with what I said once before; there has been too much Mesolithic and too little hunter-gatherers in Swedish early Stone Age research.

\section{ACKNOWLEDGEMENTS}

Helena Knutsson, Uppsala university, introduced me to the revisionist debate on $\mathrm{HG}$ groups in anthroplogy. It is obviously of fundamental importance so I am greatful for that help.

English revised by Laura Wrang.

the first 6000 years. Swedish Archaeology 1981-1985:37-46. Stockholm.

Brown, J. A. \& Price, T. D. 1985 (Eds). Prehistoric Hunter-Gatherers. The Emergence of Cultural Complexity. Studies in Archaeology.

Callahan, E. 1987. An evaluation of the lithic technology in middle Sweden during the Mesolithic and Neolithic. AUN 8. Uppsala.

Eliasson, L. \& Joelsson, J. 1989. Knivar och spetsar. En jämförande studie av skifferföremål frän Västerbottens kust-och inland. Seminar paper. Umeå.

Engelstad, E. 1986. Gender studies - A Stone Age perspective. Kontaktstencil nr 28/29.

- 1991. Gender and the use of household space. An ethnoarchaeological approach. In: (Eds Grön, O. \& Engelstad, E.). Social Space. Human Spatial Behaviour in Dwellings and 
Settlements. Odense university studies in History and Social Sciences vol 147:49-54. Odense.

Forsberg, L. 1986. Site Variability and Settlement Patterns. Archaeology and Environment 5. Umeå.

- 1989. Economic and social change in the interior of Northern Sweden 6000 B. C. - 1000 A. D. In: Larsson, T. B. \& Lundmark, H. (Eds). Approaches to Swedish prehistory: BAR. Int. Ser. 500:55-82.

Gräslund, B., Knutsson, H., Knutsson, K. \& Taffinder, J. (Eds). 1990. The interpretative possibilities of microwear studies. Proceedings of the international conference on lithic use-wear analysis, 15th-17th February 1989 in Uppsala, Sweden. AUN 14. Uppsala.

Gustafsson, K. 1987. Stenåldersfynd från Bjärehalvön. Seminar paper. Lund.

Holm, L. 1989. Manufacture of stone tools in Northern Sweden- a study of stone assemblages in the Caledonian chain. In: Approaches to Swedish prehistory. (Eds) Larsson, T. B. \& Lundmark, H. BAR Int. Ser. 500: 191-210.

- 1990. The use of stone in the Rana-Tärna region, North Scandinavia. Universitetets Oldsakssamlings Årbok, 1989/1990:85-91. Oslo.

Hyenstrand, $\AA$. 1987. Stone age frontiers - an example from Middle Sweden. In: G. Burenhult, A. Carlsson, Å. Hyenstrand, T. Sjøvold (Eds.) Theoretical Approaches to Artefacts, Settlement and Society. BAR, Int. Ser. 366.

Högberg, N.G. 1987. Stenåldersbosättningar $i$ västra Småland. Seminar paper. Lund.

Ingold, T., Rickes, D. \& Woodburn, J. 1988. Hunters and Gatherers. Vol 1: History, Evolution and social change. London.

Jacobsson, K. 1987. Horn- och benhantverk $i$ Skateholm. Seminar paper. Lund.

Jansson, B. 1987. Några stenåldersboplatser $i$ Höks härad. Seminar paper. Lund.

Jennbert, K. 1984. Den produktiva gåvan. Tradition och innovation $i$ Sydskandinavien för omkring 5300 år sedan. Acta Archaeologica Lundensia. Series in $4^{\circ}$. Nr 16. Lund.

Johansson, L.G. 1989. Var Tingbyhuset från järnåldern? Populär arkeologi 7/2:311-32.

Jonsson, L. 1986. Fish bones in Late Mesolithic human graves at Skateholm, Scania, South Sweden. In: Fish and archaeology. BAR, Int. Ser. 294:62-79. Eds D.J. Brinkhuisen \& A.T.
Clason.

Juel-Jensen, H. 1985. A functional Study of Lithics from Vænget Nord, a Mesolithic Site at Vedbæck, N. E. Sjælland. Journal of Danish Archaeology. Vol. 4. pp. 40-51.

Karsten, P. 1986. Jägarstenåldern kring Yddingen. Limhamniana 28:65-89. Malmö.

Knutsson, H. \& Taffinder, J. 1986. Microwear traces on porphyry and hälleflint. Preliminary results of experiments. Early Man News 9-11/ 1-2:29-33. Tübingen.

Knutsson, H. 1982. Skivyxor. Experimentell analys av en redskapstyp från den senatlantiska bosättningen vid Soldattorpet. Seminar paper. Uppsala.

Knutsson, K. 1976. Skrapor och skrapning. Seminar paper. Uppsala.

1985. Barn, finns dom? Fjölnir, nr 2/1:8-11. Uppsala.

- 1986. Några ord om barn, stötkantkärnor och Piéces Esquillées. Fjölnir, nr 5:1:29-39. Uppsala.

- 1988a. Patterns of tool use. AUN 10. Uppsala.

- 1988b. Making and using stone tools. The analysis of the lithic assemblages from Middle Neolithic sites with flint in Västerbotten, northern Sweden. AUN 11. Uppsala.

- 1990. A New Lithic Scene. The archaeological context of used tools. In: (Eds Gräslund, B., Knutsson, H., Knutsson K., \& Taffinder, J.) Interpretative possibilities of microwear studies. AUN 14. Uppsala.

Knutsson, K. \& Lekberg, P. 1994. Grävningsmetod i Fågelbacken 1993-1994. In: Lekberg (Ed.) Fågelbacken. Rapporter från Arkeologikonsult AB. Upplands-Väsby.

Larsson, L. 1986a. Ethnicity and traditions in Mesolithic mortuary practices in southern Scandinavia. In: Multiculturalism and ethnicity in archaeological interpretation. (Eds. Allen \& Unwin: 1986. World Archaeological Congress, preprints, 4. Southampton.

- 1986b. Skateholm. Skalk 1986:4:21-30.

- 1987. Some aspects of cultural relationship and ecological conditions during the late Mesolithic and early Neolithic. In: Theoretical approaches to Artefacts, Settlement and Society. BAR Int. Ser. 366:165-176.

$-1988 \mathrm{a}$. Late Mesolithic settlements and cemeteries at Skateholm, Southern Sweden. In: The Mesolithic in Europe. Papers presented at the Third International Symposium, Edinburgh 
1985. (Ed C. Bonsall). Edinburgh. 367-378.

- 1988b. The Skateholm Project I. Man and environment. Lund.

- 1989. Big Dog and Poor Man. Mortuary practice in mesolithic societies in southern Sweden. In: Approaches to Swedish prehistory. BAR Int. ser. 500:211-223. (Eds T. B. Larsson \& H. Lundmark).

- 1989b. Ethnicity and traditions in mesolithic mortuary practice of southern Scandinavia. In: Archaeological approaches to cultural identity. (Ed J. Shennan). London. 210-218. - 1990a. The mesolithic of Southern Scandinavia. Journal of World prehistory 4/3:257-309.

- 1990b. Sydskånsk öbosättning. Boplatslämningar från jägarstenålder och sen vikingatid tidig medeltid vid Ellestadsjön. Ale, 1989/4: 1-11.

- 1990c. Aspekter på gravskick hos förhistoriska fångstsamhällen. Kungliga Vitterhets- Historie- och Antikvitetsakademins Årsbok 1990. Stockholm. 104-115.

- 1990d. Senpaleolitisk bosättning i Sydsverige. Undersökningar i ett marginalområde. Genetik och Humaniora 2:45-52. Lund.

- 1990e. Dogs in Fraction - Symbols in Action. In: Contributions to the Mesolithic of Europe. (Eds M. Vermeersch \& P. van Peer). Leuwen. 153-160.

Larsson, M. 1986. Bredasten - an early Ertebölle site with a dwelling structure in South Scania. Meddelanden frän Lunds Universitets Historiska Museum. Nr 6:25-51. Lund.

- 1987. The Neolithisation in Scania - A Funnel Beaker Perspective. Journal of Danish Archaeology 5:244-247. Odense.

- 1989. Stenåldersjägare i Ystads Sandskog. Ystadiana 34:21-28. Ystad.

Lee, R. B. 1992. Art, Science or Politics? The Crisis in Hunter-gatherer Studies. American Anthropologist 94:1:31-54.

Lenski, G. \& Lenski, J. 1987. Human societies: an introduction to macrosociology. New York. 5 edition.

Lindgren, C. 1990. En nyupptäckt stenåldersboplats i Östergötland. Arkeologi i Sverige. $N y$ följd 1. Stockholm.

Lindholm, P. \& Runesson, H. 1990. Trindyxor $i$ Norrland och Dalarna. Seminar paper.Umeå.

Lindow, B. 1987. Skateholm III. En senatlantisk boplats. Seminar paper. Lund.

Lundberg, Å. 1986. Skärvstenvallar i Norrland.
Studier i Norrländsk forntid II. Acta Bothensia Occidentalis. Skrifter i västerbottnisk kulturhistoria. 8:81-99. Umeå.

Nordqvist, B. 1989. Västsvenska storviltsjägare. Populär arkeologi 7/1:8-9.

- 1990. Här gjordes stenyxor för hemmabruk. Populär arkeologi 8/1:17-18.

Olausson, D. 1986. Intra site spatial analysis in Scandinavian archaeology. Meddelanden frän Lunds Universitets Historiska Museum. New Series, 6. Lund.

Persson, P. 1989. Bofasthet under mesoliticum? Kontakstencil 30-31:98-115.

Pålsson, B. 1987. Limhamns förhistoria. Seminar paper. Lund.

Rajala, E. \& Westergren, E. 1990. Tingby- a Mesolithic site with the remains of a house, to the West of Kalmar, in the province of Smaland. Nicolay 52/2-53/1:5-30. Oslo.

Ramos-Millán, A. 1990. Use-Wear Analysis and Archaeological Theory. A Restatement of Current Problems. In: The interpretative possibilities of microwear studies. Proceedings of the international conference on lithic usewear analysis, 15-17th February 1989 in Uppsala. AUN 14:22-39. Uppsala.

Rosberg, A. 1987. Hundliv - om hunden $i$ stenålderssamhället. Seminar paper. Lund.

Schaller Åhrberg, E. \& Kindgren, H. 1990. Kökkemöddingen låg mitt i vägen. Populär arkeo$\log i$ 8/1:19-22.

Schiffer, H. B. 1976. Behavioural archaeology.

Selling, A. 1987. Idag röd, i morgon död. Seminar paper. Lund.

Skar, B. 1987. The Scanian Maglemose site Bare Mosse II. A re-examination by refitting. Acta Archaeologica 58:87-104 Köpenhamn.

Strömberg, M. 1986. Signs of Mesolithic occupation in South-East Scania. Meddelanden från Lunds Universitets Historiska Museum. Nr 6: 52-83. Lund.

- 1989. Similarities and differences in the utilisation of certain resources in the Hagestad area, southern Sweden. In: Approaches to Swedish prehistory. BAR Int. ser. 500:225-237. Eds: T.B. Larsson \& H. Lundmark.

Streiffert, J. 1986. Boplatslämningar i gasledningens sträckning. Fynd 2:86:30-34. Göteborg.

Sundlin, H. 1986. Gammal datering från Åsele. In: Studier $i$ Norrländsk forntid 2:132-136. Umeå.

Taffinder, J. 1987. The selection of lithic raw ma- 
terials. Tor 21:57-77. Uppsala.

Tesch, S. 1993. Houses, Farmsteads, and Long-term Change. A regional Study of Prehistoric Settlements in the Köpinge Area, in Scania, Southern Sweden. Uppsala.

Testart, A. 1988. Some major problems in the social anthropology of hunter-gatherers. Current Anthropology 29:1-31.

Thorsberg. K. 1984. Analys av boplatser. Teori och metoder. Seminar paper. Uppsala.

- 1986. Myten om eggvinkeln. Fjölnir nr 5:1:4171. Uppsala.

- 1990. The meaning of microwear data. In: The interpretative Possibilities of Microwear Studies. (Eds.) Gräslund, B., Knutsson, H., Knutsson, K. \& Taffinder, J. AUN 14. Uppsala.

Tilley, C. 1989. Hunter-gatherer, farmers and the social structuring of material culture. In: Approaches to Swedish prehistory. BAR Int. ser. 500:239-285. Eds T. B. Larsson \& H. Lundmark.

Welinder, S. 1988. Mesolithic forest clearance in Scandinavia. The Mesolithic in Europe.
Papers presented at the Third International Symposium, Edinburgh 1985. (Ed. C. Bonsall). Edinburgh. 362-366.

- 1989. 3 x stenåldern. Populär Arkeologi, 7:1. Lund.

Westergren, E. 1988. Kalmarbygden fick en "ny" stenålder. Populär arkeologi 6/1:20-23.

Westergren, E. \& Hansson, A. 1987. Nya rön om stenåldern och bronsåldern i Kalmar län. Kalmar län 72:31-47. Kalmar.

Westergren, E. \& Rajala, E. 1989. Tingby stenåldersboplats 1988. Kalmar län 74:149-153. Kalmar.

Westfal, U. 1987. Vuollerimundersökningarna. Norrbotten 1987. Luleå. 24-31.

Österholm, I. 1988. Stenåldersforskning på Gotland. Populär Arkeologi, 6:2.

- 1989. Bosättningsmönstret på Gotland under stenåldern. En analys av fysisk miljö, ekonomioch social struktur. Theses and Papers in Archaeology. New series 3. Stockholm. 
